\title{
Deregulation in Retailing: The Dutch Experience
}

Citation for published version (APA):

Carree, M. A., \& Nijkamp, J. (2001). Deregulation in Retailing: The Dutch Experience. Journal of Economics and Business, 53, 225-235. https://doi.org/10.1016/S0148-6195(00)00052-7

Document status and date:

Published: 01/01/2001

DOI:

10.1016/S0148-6195(00)00052-7

Document Version:

Publisher's PDF, also known as Version of record

\section{Please check the document version of this publication:}

- A submitted manuscript is the version of the article upon submission and before peer-review. There can be important differences between the submitted version and the official published version of record.

People interested in the research are advised to contact the author for the final version of the publication, or visit the DOI to the publisher's website.

- The final author version and the galley proof are versions of the publication after peer review.

- The final published version features the final layout of the paper including the volume, issue and page numbers.

Link to publication

\footnotetext{
General rights rights.

- You may freely distribute the URL identifying the publication in the public portal. please follow below link for the End User Agreement:

www.umlib.nl/taverne-license

Take down policy

If you believe that this document breaches copyright please contact us at:

repository@maastrichtuniversity.nl

providing details and we will investigate your claim.
}

Copyright and moral rights for the publications made accessible in the public portal are retained by the authors and/or other copyright owners and it is a condition of accessing publications that users recognise and abide by the legal requirements associated with these

- Users may download and print one copy of any publication from the public portal for the purpose of private study or research.

- You may not further distribute the material or use it for any profit-making activity or commercial gain

If the publication is distributed under the terms of Article $25 \mathrm{fa}$ of the Dutch Copyright Act, indicated by the "Taverne" license above, 


\title{
Deregulation in retailing: the Dutch experience
}

\author{
Martin A. Carree ${ }^{\mathrm{a}, \mathrm{b}, *}$, Joyce Nijkamp ${ }^{\mathrm{c}}$ \\ ${ }^{a}$ Faculty of Economics, Erasmus University Rotterdam, P.O. Box 1738, 3000 DR Rotterdam, The Netherlands \\ ${ }^{\mathrm{b}}$ Faculty of Economics and Business Administration, Maastricht University, P.O. Box 616, \\ 6200 MD Maastricht, The Netherlands \\ ${ }^{\mathrm{c}}$ Tinbergen Institute Rotterdam, Faculty of Economics, Erasmus University Rotterdam, P.O. Box 1738, \\ 3000 DR Rotterdam, The Netherlands
}

Received 1 September 1999; received in revised form 1 May 2000; accepted 12 May 2000

\begin{abstract}
Institutional barriers to entry were removed to a considerable extent in 1996 in the Dutch retail sector to enhance market dynamics. Three years before that the regulator decided to not take legal actions anymore against entrants violating institutional requirements. In the current analysis we investigate the effects of the deregulation during that 1993-1995 period using a recently developed model by Carree and Thurik (1999). The results show that the equilibrium number of firms and the adjustment speed from the disequilibrium number of firms to the equilibrium number have both increased. The results also show that the increase in the speed of adjustment is the consequence of lowering barriers to entry. (C) 2001 Elsevier Science Inc. All rights reserved.
\end{abstract}

JEL classification: K23; L50; L81

Keywords: Deregulation; Entry barriers; Retailing

\section{Introduction}

Starting a retail venture was subject to important institutional requirements in the Netherlands up till 1996. The institutional entry requirements in Dutch retailing were based upon a forty year old law, the Vestigingswet Bedrijven 1954, which applied to the start up of a company or a new establishment. The main goal of the law was to promote an adequate

* Corresponding author. Tel.: +31-43-3883763.

E-mail address: m.carree@mw.unimaas.nl (M. Carree). 
conduct of business. 'Adequate' conduct concerned protecting consumers from incompetence and having sound book-keeping. Starting a new company or establishment required at least the middenstandsdiploma. The middenstandsdiploma is a retailer's certificate which covers basic commercial and accounting skills. For most shoptypes additional certificates were required with respect to professional skills. These are shoptype-specific requirements for which additional schooling is needed. ${ }^{1}$ Moreover, the demarcation of shoptypes, with every shoptype its own professional (entry-)requirements, was on a very disaggregated level and had become outdated, i.e. related to production techniques of the 1950s. Because for many retail activities, professional skills were required, this strongly limited the freedom to enter, to diversify and to pursue even closely related entrepreneurial activities.

The institutional requirements were an important barrier to entry in the retail sector in the Netherlands. International comparative studies show that the institutional requirements for starting entrepreneurs in the Netherlands were one of the highest within Europe (EIM, 1993). Besides the institutional requirements, other barriers to start a retail venture are relatively low. The setting up of a shop generally demands much less capital, time and knowledge investment than starting an enterprise in manufacturing. This is due to the more limited size of retail shops and the more clearly structured retail market environment resulting from the limited impact of innovations and international competition.

Despite concerns of representatives of incumbent retailers, the Dutch government decided to lower the institutional barriers to entry in order to enhance market performance. ${ }^{2}$ A key aim of the deregulation was to increase market dynamics by simplifying (new) entry. The new law results in a decrease of the height of entry barriers in three ways. First, the middenstandsdiploma was replaced by a retailer's certificate (called $A O V$ ) for which the workload in terms of study hours is reduced (from about $240 \mathrm{hr}$ to about $120 \mathrm{hr}$ ). Second, in the new law only for a very limited number of shoptypes additional certificates with respect to professional skills are still required. ${ }^{3}$ Third, such requirements are no longer related to separate establishments and shoptypes, but to companies and clusters of shoptypes. This leaves retailers much more flexible in diversifying into related entrepreneurial activities.

Although the institutional entry requirements were changed in 1996, it was already announced in mid 1992 that from the 1st of January 1993 on, there would be no (criminal) prosecution by the regulator anymore. We investigate for this first period, 1993-1995, the effects of deregulation on entry, exit and number of shops in retail markets. For this we use an extension of a recently developed model by Carree and Thurik (1999). This model allows for the measurement of the speed of adjustment towards the equilibrium average number of firms in local retail markets and the computation of the contributions of entry flows and exit flows to this adjustment process. Additionally, the change in the equilibrium number of firms resulting from deregulation can be estimated.

Aggregate data on entry and exit rates of entrepreneurs in Dutch retailing suggest that market dynamics have increased in the period 1993-1995. Bosma and Zwinkels (1999) provide data showing that the average new entry rate in the retail sector increased by $28 \%$ when comparing the 1993-1995 period with the 1987-1992 period. The average exit rate increased as well, by $22 \%$. In the current paper we provide statistics on the effect of deregulation at the much more disaggregate level of shoptypes (retail industries). We use data of 23 shoptypes covering the period 1981-1995. The rest of the paper is organized as 
follows. In Section 2 we develop our error correction model which we use to measure the deregulation effects. Section 3 is used to describe the panel data set and some basic statistics of the Dutch retail sector. In Section 4 we present the empirical results and Section 5 concludes.

\section{The model}

Retailing constitutes a relatively simple entrepreneurial activity. There are no huge barriers to entry although there are several factors which may lengthen the time between deciding to start a retail venture and the actual entry. Such factors may include finding an adequate sales outlet, arranging credit and passing the exam(s) for retailer's certificates. A clear indication that entry barriers in the retail sector are not very high, is the limited difference between the rewards for running a store and the average wage level. Carree and Thurik (1999) report that the average reward for entrepreneurial activities in Dutch retailing in the 1980s has been about 50\% more than that for the activities of a (modal) employee. In case retail profits increase relative to the wage level we expect an increase in the (net) entry rate, while in the reverse case we expect more (net) exit.

Carree and Thurik (1999) model the retail market structure as follows. They assume that each local retail market has an equilibrium number of enterprises, $N^{*}$. This equilibrium number is determined, among others, by a critical profit level, $\pi^{*}$ and total market demand, $Q$. A decrease in the critical profit level that entrepreneurs expect for their activities or as compensation for the entrepreneurial risks, leads to an increase in the equilibrium number of firms. An increase in demand also increases the equilibrium number of firms:

$$
\begin{aligned}
& v_{\pi}=\frac{\partial N^{*}}{\partial \pi^{*}} \frac{\pi^{*}}{N^{*}}<0 \\
& v_{Q}=\frac{\partial N^{*}}{\partial Q} \frac{Q}{N^{*}}>0
\end{aligned}
$$

Carree and Thurik also derive from their (oligopoly) model that $\nu_{Q}$ should be smaller than 0.5 (p. 989). The change in the equilibrium number of firms from one period to another can be approximated by: ${ }^{4}$

$$
g_{t}=\frac{\Delta N_{t}^{*}}{N_{t-1}^{*}} \approx \alpha+v_{\pi} \frac{\Delta \pi_{t}^{*}}{\pi_{t-1}^{*}}+v_{Q} \frac{\Delta Q_{t}}{Q_{t-1}}
$$

The parameter $\alpha$ is incorporated to correct for a structural development in the equilibrium number of firms. The Dutch retail sector has gone through a period of concentration for the past decades (Nooteboom, 1986). Supermarkets have gained market share at the expense of specialized food stores like butchers and greengrocers. Not every shoptype may have suffered to the same extent from such developments, so the structural development parameter may differ across shoptypes. The most important distinction is that between food and nonfood shoptypes, because food shoptypes will have suffered most strongly from the 
increased market shares of supermarkets. We will therefore present results for those two separate groups of shoptypes.

Carree and Thurik assume that entrepreneurs adjust for disequilibria as these are characterized by profit opportunities. This reasoning is in line with the Kirznerian notion of entrepreneurial activity resulting from the perception of available opportunities to make profits (Kirzner, 1973, 1979, 1997). They derive under certain assumptions that the actual number of firms is determined by an error correction model of the form:

$$
\Delta \ln \left(N_{t}\right)=\gamma_{t}\left(\ln \left(N_{t-1}^{*}\right)-\ln \left(N_{t-1}\right)\right)
$$

An extension to the Carree and Thurik model is that we assume that the speed of adjustment parameter $\gamma_{t}$ is time-dependent. We make this extension as we expect the speed of adjustment before and after the deregulation to be different. We do not know the value of the equilibrium number of firms, but we may derive Eq. (5) from Eq. (4):

$$
\Delta \ln \left(N_{t}\right)-\frac{\gamma_{t}}{\gamma_{t-1}} \Delta \ln \left(N_{t-1}\right)=\gamma_{t}\left(\Delta \ln \left(N_{t-1}^{*}\right)-\Delta \ln \left(N_{t-1}\right)\right)
$$

Considering that $\ln (1+x) \approx x$ when $x$ is small and adding a disturbance term, we have:

$$
\Delta \frac{\Delta N_{t}}{N_{t-1}}=\frac{\gamma_{t}-\gamma_{t-1}}{\gamma_{t-1}} \frac{\Delta N_{t-1}}{N_{t-2}}+\gamma_{t}\left(g_{t-1}-\frac{\Delta N_{t-1}}{N_{t-2}}\right)+e_{t}
$$

We make the following assumptions about the speed of adjustment parameter $\gamma_{t}$ and the critical level of profits $\pi_{t}^{*}$. We assume that $\gamma_{t}$ takes two values, $\gamma_{B}$ before the deregulation (up till 1992) and $\gamma_{A}$ after the deregulation (from 1993 on). We assume that the critical level of profits $\pi_{t}^{*}$ is constant in both regulation periods, but not for the deregulation date (1st of January 1993) when it shifts downwards. The general real wage index in the Netherlands barely changed during the period of investigation, which indicates that an assumption of a constant $\pi_{t}^{*}$ should not pose a problem. However, due to the deregulation measures retail ventures have become easier to start. It is therefore likely that the critical level of profit (compared to the wage level) to enter has gone down. So, Eq. (6) has a different expression before, during and after the deregulation year (1993): ${ }^{5}$

$$
\begin{aligned}
& \Delta \frac{\Delta N_{t}}{N_{t-1}}=\gamma_{B}\left(\alpha+v_{Q} \frac{\Delta Q_{t-1}}{Q_{t-2}}-\frac{\Delta N_{t-1}}{N_{t-2}}\right)+e_{t} \quad \mathrm{t}<1993 \\
& \Delta \frac{\Delta N_{t}}{N_{t-1}}=\frac{\gamma_{A}-\gamma_{B}}{\gamma_{B}} \frac{\Delta N_{t-1}}{N_{t-2}}+\gamma_{A}\left(\alpha+\beta+v_{Q} \frac{\Delta Q_{t-1}}{Q_{t-2}}-\frac{\Delta N_{t-1}}{N_{t-2}}\right)+e_{t} \quad \mathrm{t}=1993 \\
& \Delta \frac{\Delta N_{t}}{N_{t-1}}=\gamma_{A}\left(\alpha+v_{Q} \frac{\Delta Q_{t-1}}{Q_{t-2}}-\frac{\Delta N_{t-1}}{N_{t-2}}\right)+e_{t} \quad \mathrm{t}>1993
\end{aligned}
$$

where $\beta$ is equal to $\nu_{\pi} \Delta \pi_{1993}^{*} / \pi_{1992}^{*}$. Our two main hypotheses with regard to the effects of the deregulation are that the deregulation leads to an increase in the adjustment speed and to an increase in the equilibrium number of firms. ${ }^{6}$ 
H1: $\gamma_{A}-\gamma_{B}>0$

H2: $\beta>0$

Carree and Thurik also derive how the flows of gross entry and gross exit contribute to the adjustment process towards the equilibrium number. For example, in case the actual number exceeds the equilibrium number of firms, adjustment may take place due to decreasing entry rates or due to increasing exit rates. The relative importance of entry and exit in the adjustment process can be estimated by replacing $\Delta\left(\Delta N_{t} / N_{t-1}\right)$ in Eqs. (7a) and (7c) by $\Delta\left(E n t_{t} / N_{t-1}\right)$ and $\Delta\left(E x t_{t} / N_{t-1}\right)$, respectively. The variables Ent $t_{t}$ and $E x t_{t}$ represent the gross number of entrants and exiting firms, and $\Delta N_{t}=E n t_{t}-E x t_{t}$. The Eqs. (8a) through (9b) show the equations to be estimated: ${ }^{7}$

$$
\begin{array}{ll}
\Delta \frac{E n t_{t}}{N_{t-1}}=\gamma_{B}^{E}\left(\alpha+v_{Q} \frac{\Delta Q_{t-1}}{Q_{t-2}}-\frac{\Delta N_{t-1}}{N_{t-2}}\right)+e_{t}^{E} & \mathrm{t}<1993 \\
\Delta \frac{E n t_{t}}{N_{t-1}}=\gamma_{A}^{E}\left(\alpha+v_{Q} \frac{\Delta Q_{t-1}}{Q_{t-2}}-\frac{\Delta N_{t-1}}{N_{t-2}}\right)+e_{t}^{E} & \mathrm{t}>1993 \\
\Delta \frac{E x t_{t}}{N_{t-1}}=\gamma_{B}^{X}\left(\alpha+v_{Q} \frac{\Delta Q_{t-1}}{Q_{t-2}}-\frac{\Delta N_{t-1}}{N_{t-2}}\right)+e_{t}^{X} & \mathrm{t}<1993 \\
\Delta \frac{E x t_{t}}{N_{t-1}}=\gamma_{A}^{X}\left(\alpha+v_{Q} \frac{\Delta Q_{t-1}}{Q_{t-2}}-\frac{\Delta N_{t-1}}{N_{t-2}}\right)+e_{t}^{X} & \mathrm{t}>1993
\end{array}
$$

Eqs. (8) and (9) are a system of two equations where the error terms $e_{t}^{E}$ and $e_{t}^{X}$ are expected to be positively correlated. Our hypotheses with regard to the effect of the deregulation are that the contribution of entry to the adjustment process increases while there is no ex ante reason to assume that the adjustment parameter for exit would become different.

$$
\begin{aligned}
& \text { H3: } \gamma_{A}^{E}-\gamma_{B}^{E}>0 \\
& \text { H4: } \gamma_{A}^{X}-\gamma_{B}^{X}=0
\end{aligned}
$$

\section{The data}

The retail sector has an important contribution to the Dutch economy. It accounted for about $23 \%$ of the total number of economically active enterprises and for about $13 \%$ of the total labor force in the Dutch private sector in 1988 (Bode, 1990). The vividity of entry and exit movements of establishments in Dutch retailing has been relatively high. The average gross entry rate per annum across all shoptypes in our sample is $8.5 \%$ while the average gross exit rate is $9.5 \%$. Entry and exit rates of establishments in shoptypes are also highly correlated (average correlation coefficient of 0.66). This implies that shoptypes which have high entry rates can also be expected to have high exit rates and vice versa. It is in accordance with Dunne et al. (1988) who present an overview of entry and exit rates in U.S. manufacturing industries.

The data concerning demand changes for products sold in shoptypes $\left(\Delta Q_{t-1} / Q_{t-2}\right.$ in the 
model) are compiled from two data sources from Statistics Netherlands (CBS). The first data source is the yearly survey on household expenditures shares. The yearly survey sample size is several thousands of households and the surveys should therefore present a reliable picture of the structural developments of the expenditure shares. Nevertheless, there appear to be some changes in the expenditure shares data from one year to another, especially in small expenditure classes, which should be subscribed to sample variation. We corrected for that by estimating a linear approximation to the expenditure shares data. That is, we estimated the equation $E S_{j t}=a_{j}+b_{j} t+\epsilon_{j t}$, where $E S$ stands for Expenditure Share (the sum of all expenditures is 1000), $j$ for shoptype and $t$ for time, and constructed the fitted series $E S_{j t}^{f i t}=$ $\hat{a}_{j}=\hat{b}_{j} t$ (see also Appendix A). This equation is estimated for each shoptype separately. Note that the sum of the expenditure shares for the shoptypes does not add to 1000 as total expenditures include many more categories like insurance, heating, transport, etc. which are not included. Finally, the demand changes for products sold are computed as $\Delta Q_{t} / Q_{t-1}=$ $\left\{E S_{j t}^{f i t}\left(1+G C S_{t}\right)-E S_{j, t-1}^{f i t}\right\} / E S_{j, t-1}^{f i t}$ where GCS stands for Growth of total Consumer Spending. Data for these percentages of growth are given in Table 1. The data show that the final years of the sample, during which the deregulation was announced, do not show extraordinarily high or low growth figures.

The net entry, gross entry and gross exit rates have been compiled using data on numbers of entering and exiting establishments and total number of establishments from the Central Registration Office (CRK) in The Hague. Note that we use entry and exit of establishments instead of companies, because the institutional requirements before deregulation were applied to establishments instead of to companies. The data are on a shoptype level in which establishments sell relatively homogeneous goods. An overview of the shoptypes together with average entry and exit rates is given in the Appendix. For 21 shoptypes we have available data over the 1981-1995 period (15 observations). For one shoptype (textiles) the data became available at a more disaggregated level from 1989 on. Therefore, we have 8 observations for the 'textiles' shoptype from 1981 to 1988 . For the 1990-1995 period (6 observations) we use data for two shoptypes which were originally included in the 'textiles' shoptype: men's clothing stores and furnishing stores. This makes a total of 335 observations. The data given in the Appendix show that shoptypes for which the expenditure shares have tended to decrease relatively strongly, like for the butcher's shops and the dairy shops, also show clearly negative average net entry rates.

\section{Empirical results}

In this section the empirical results of Eqs. (7), (8) and (9) are presented. Table 2 shows the estimation results for the net entry Eq. (7). In the first column of the table the results are presented when taking all observations into account. The speed of adjustment before the deregulation is estimated to be 0.531 . This means that more than half of the disequilibrium is corrected for within a one-year period. After the deregulation the speed of adjustment parameter increases by 0.138 , but this increase is not significant at the $10 \%$ level. The structural trend in the equilibrium number of firms in retailing over the 1981-1995 period is negative and significant. However, the deregulation has led to an increase of this number (the 
Table 1

Real growth of total consumer expenditures (1980-1994)

\begin{tabular}{llllll}
\hline Year & Growth & Year & Growth & Year & Growth \\
\hline 1980 & $-0.4 \%$ & 1985 & $2.8 \%$ & 1990 & $4.2 \%$ \\
1981 & $-3.0 \%$ & 1986 & $2.6 \%$ & 1991 & $3.1 \%$ \\
1982 & $-0.5 \%$ & 1987 & $2.7 \%$ & 1992 & $2.5 \%$ \\
1983 & $1.0 \%$ & 1988 & $0.8 \%$ & 1993 & $1.0 \%$ \\
1984 & $1.2 \%$ & 1989 & $3.5 \%$ & 1994 & $2.2 \%$ \\
\hline
\end{tabular}

coefficient for $\beta$ is positive and significant). This increase is equivalent to the negative of more than three years, on average, of structural decrease. Therefore, while we find evidence for the second hypothesis of a temporary increase in the equilibrium number of firms to be valid, we fail to find sound evidence for the first hypothesis of an increased speed of adjustment.

In the second column of the table we show the results when leaving out one of the shoptypes, viz. the furniture stores. This shoptype has the largest average floorspace per firm of all shoptypes in the sample. This indicates that entry barriers with respect to capital investment may be quite large. Therefore, we expect the deregulation to have had much less effect on the barriers to entry in this shoptype when compared to the rest of the shoptypes in our sample. The estimated increase in the adjustment parameter after the deregulation date is indeed higher when leaving the Furniture Stores out of the data set. The coefficient of 0.194 is significant at the $5 \%$ level. That is, there is some evidence for the first hypothesis to be valid.

It is likely that average adjustment rates and the structural development in the carrying capacity differ between shoptypes. When we split the sample in food and nonfood shoptypes we find that the results differ considerably both with respect to the structural trend of the

Table 2

Estimation results for the net entry equation (7)

\begin{tabular}{lccccc}
\hline & & No Furniture & No 1993 & Non-Food & Food \\
\hline$\gamma_{\mathrm{B}}$ & 0.531 & 0.513 & 0.508 & 0.512 & 0.602 \\
& $(11.57)$ & $(11.30)$ & $(9.48)$ & $(8.82)$ & $(7.76)$ \\
$\gamma_{\mathrm{A}}-\gamma_{\mathrm{B}}$ & 0.138 & 0.194 & 0.204 & 0.296 & -0.017 \\
& $(1.48)$ & $(2.12)$ & $(1.66)$ & $(2.15)$ & $(0.12)$ \\
$\alpha$ & -0.008 & -0.009 & -0.008 & -0.005 & -0.013 \\
& $(3.57)$ & $(4.08)$ & $(3.33)$ & $(1.77)$ & $(3.67)$ \\
$\beta$ & 0.027 & 0.029 & & 0.016 & 0.035 \\
& $(3.59)$ & $(4.14)$ & 0.345 & $(1.82)$ & $(2.80)$ \\
$\nu_{\mathrm{Q}}$ & 0.334 & 0.317 & $(4.11)$ & $(1.83)$ & 0.326 \\
$\mathrm{R}^{2}$ & $(4.17)$ & $(4.13)$ & 0.300 & 0.289 & $0.32)$ \\
$\mathrm{N}$ & 0.301 & 0.314 & 312 & 200 & 0.348 \\
\hline
\end{tabular}

Note: Absolute t-values in parentheses. In the second column the shoptype Furniture Stores is left out. In the third column the year 1993 is left out (to facilitate comparison with the results in Table 3) and in the last two columns we show results for the non-food and food shoptypes separately. 
Table 3

Estimation results for the system of entry and exit equations (8) and (9)

\begin{tabular}{lcccr}
\hline & & No Furniture & Non-Food & Food \\
\hline$\gamma_{B}^{E}$ & 0.228 & 0.219 & 0.179 & 0.305 \\
& $(4.65)$ & $(4.34)$ & $(3.15)$ & $(3.38)$ \\
$\gamma_{A}^{E}-\gamma_{B}^{E}$ & 0.209 & 0.235 & 0.419 & $(0.095$ \\
& $(1.91)$ & $(2.15)$ & $(3.13)$ & $-0.52)$ \\
$\gamma_{B}^{X}$ & -0.277 & -0.284 & -0.265 & $(3.68)$ \\
& $(6.16)$ & $(6.09)$ & $(5.41)$ & -0.015 \\
$\gamma_{\mathrm{A}}^{\mathrm{X}}-\gamma_{\mathrm{B}}^{\mathrm{X}}$ & 0.007 & 0.011 & 0.035 & $(0.08)$ \\
& $(0.07)$ & $(0.11)$ & $(0.32)$ & -0.013 \\
$\alpha$ & -0.009 & -0.010 & -0.007 & $(3.74)$ \\
& $(3.69)$ & $(4.19)$ & $(2.28)$ & 0.327 \\
$\nu \mathrm{Q}$ & 0.337 & 0.328 & 0.346 & $(3.34)$ \\
& $(4.02)$ & $(4.06)$ & $(1.43)$ & 0.089 \\
$R_{\mathrm{E}}^{2}$ & 0.119 & 0.122 & 0.167 & 0.114 \\
$R_{\mathrm{X}}^{2}$ & 0.121 & 0.124 & 0.152 & 126 \\
$\mathrm{~N}$ & 312 & 298 & 186 & \\
\hline
\end{tabular}

Note: Absolute t-values in parentheses. In the second column the shoptype Furniture Stores is left out. In the last two columns we show results for the non-food and food shoptypes separately.

equilibrium number of firms and with respect to the change in the adjustment speed after the deregulation in 1993. The structural decline in the equilibrium number of firms is clearly visible in food stores and more than twice as large as in nonfood stores. The food stores have lost important market share to supermarkets during the 1981-1995 period in the Netherlands. The adjustment speed seems to be unaffected by the deregulation for the food shoptypes, while it has had a large effect for the nonfood shoptypes. One reason may be that there are still some additional institutional requirements in food shoptypes like Bakers and Butchers to ensure that consumers can purchase food products without health hazards. There are also food shoptypes like Dairy Shops and Tobacco Shops which have been losing market share to supermarkets for year after year and for which entry has failed to become more attractive due to deregulation. The results for the two separate groups can be found in the last two columns of Table 2 .

Now we turn to the estimation of the system of two Eqs. (8) and (9). As we suspect the error term to be correlated, we use the method of Seemingly Unrelated Regression. The estimation results can be found in Table 3. The estimated correlation coefficient of the error terms of the two equations for the total sample is 0.35 . We find for the total sample that there is an increase in the adjustment speed for entry but not for exit. The increase found in Table 2 can therefore be contributed to relaxation of entry regulations. In accordance with the results for net entry, there are differences between food and nonfood shoptypes. Adjustment through entry has been clearly positively affected for the group of nonfood shoptypes but not so for the group of food shoptypes. In accordance with the results for net entry, we find evidence for the third hypothesis that the ease of entry has increased after the deregulation. However, this evidence is limited to the sub sample of nonfood shoptypes. We cannot reject the fourth hypothesis of the ease of exit not to be affected by the deregulation measures. Before the deregulation date the role of exit in the adjustment process was somewhat more 
important than that of entry, while after the deregulation date this has clearly reversed. In fact, the contribution of entry to the total adjustment speed after the deregulation is more than one and a half times as large as that of exit $(0.44$ versus 0.27 , total 0.71$){ }^{8}$ See the third column of Table 2 for comparison.

\section{Conclusions}

The current paper investigates the effects of the 1993 deregulation for the Dutch retail sector. From the 1st January of 1993 on the regulator decided not to take legal actions anymore against entrants violating institutional requirements. Three years later the institutional barriers to entry were officially relaxed. We investigate the effect of the deregulation during the period 1993-1995 during which legal actions were abandoned. Our results can be summarized as follows. There seems to be clear evidence for an increase in the ease of entry for nonfood shoptypes. For food shoptypes we do not find such an increase. For both food and nonfood shoptypes we find an increase in the equilibrium number of firms per local market. There appears to have been no impact on the ease of exit during the period under investigation.

We note that these results are preliminary in the sense that only the first three years after the deregulation have been investigated. Future research should throw light on the questions whether the increase in market dynamics was temporary or structural. Bosma and Zwinkels (1999) provide data for 1996 showing that for the total retail sector entry declines from 1995 to 1996 and exit increases somewhat. It may indicate that the period of 1993-1995 will turn out to be a cohort of entrants which is less successful than cohorts before the deregulation period. Research into the deregulation efforts which are taking place in retailing in other European countries would also provide much additional information about the extent to which deregulation affects market dynamics in the retail sector.

\section{Notes}

1. For instance, to start up a hairdresser's shop one needed a certificate from the hair-dressing school next to the middenstandsdiploma.

2. We do not provide a discussion of the economic literature concerning deregulation. See Phillips (1985) and Winston (1993) for some discussions on the consequences of deregulation.

3. These are baker's shops, butcher's shops, fish shops and poultry shops. The poultry shops are not included in our data set.

4. Carree and Thurik (1996) provide an overview of empirical studies into the determinants of entry and exit. In the majority of studies that consider net entry a significant positive effect of (lagged) profitability and (lagged) growth is found.

5. A statistical test of the timing of the impact of the deregulation is not pursued in our analysis because we lack enough postderegulation time period data. The deregulation effect might take a couple of years to fully develop. This implies that there should be more equations like (7b) for years like 1994 and 1995. 
6. Note that the effects of the regulatory change on adjustment speed need not go together with that on the equilibrium number of firms.

7. Note that we do not take the year 1993 into account in the estimation of Eqs. (8) and (9). This is a consequence of gross entry and exit to be determined only partly from adjustment towards equilibrium as in Eq. (4). A large share of entry and exit is turbulence, the extent of which is likely to change in 1993 as well. It is not possible to identify the shift in the growth rate of the equilibrium number of firms (parameter $3 \beta$ ) apart from the shift in the extent of turbulence. See Carree and Thurik (1999, p. 992) for more details.

8. Note that these results are based upon two postderegulation years, 1994 and 1995. The increased contribution of entry to the total adjustment speed may be partly temporary.

\section{Appendix. Average entry and exit rates and coefficients of fitted demand equation}

Table A1:

Summary statistics for the shoptypes

\begin{tabular}{|c|c|c|c|c|}
\hline Shoptype & entry rate ${ }^{a}$ & exit rate ${ }^{a}$ & $\hat{\mathrm{a}}_{\mathrm{j}}^{b}$ & $\hat{\mathrm{b}}_{\mathrm{j}}^{b}$ \\
\hline grocers/supermarkets & 0.083 & 0.104 & 203.18 & -1.62 \\
\hline greengrocers & 0.081 & 0.097 & 28.77 & -0.35 \\
\hline liquor stores & 0.086 & 0.110 & 17.68 & -0.24 \\
\hline men's clothing stores ${ }^{c}$ & 0.045 & 0.083 & 16.88 & -0.30 \\
\hline shoe stores & 0.078 & 0.083 & 12.00 & -0.05 \\
\hline furniture stores & 0.126 & 0.119 & 19.43 & -0.13 \\
\hline furnishing stores ${ }^{c}$ & 0.114 & 0.104 & 11.80 & -0.02 \\
\hline furnishing/furniture stores (mixed) & 0.064 & 0.083 & 38.01 & 0.04 \\
\hline bicycle stores & 0.046 & 0.058 & 3.91 & 0.05 \\
\hline jewelleries & 0.086 & 0.082 & 2.71 & 0.02 \\
\hline drug stores & 0.067 & 0.063 & 10.90 & 0.38 \\
\hline florists & 0.122 & 0.114 & 6.59 & -0.02 \\
\hline butcher's shops & 0.075 & 0.093 & 26.04 & -0.70 \\
\hline dairy shops & 0.051 & 0.091 & 32.79 & -1.69 \\
\hline fish shops & 0.118 & 0.109 & 3.06 & -0.03 \\
\hline baker's shops & 0.072 & 0.082 & 13.32 & -0.21 \\
\hline confectioners & 0.113 & 0.117 & 13.91 & -0.03 \\
\hline tobacco shops & 0.042 & 0.079 & 12.76 & -0.26 \\
\hline household goods shops & 0.094 & 0.095 & 8.00 & -0.08 \\
\hline paint, glass and wall-paper stores & 0.057 & 0.078 & 4.93 & -0.08 \\
\hline hardware stores & 0.066 & 0.081 & 5.51 & -0.06 \\
\hline photographer's shops & 0.092 & 0.082 & 6.07 & -0.10 \\
\hline pet shops & 0.101 & 0.096 & 6.43 & 0.01 \\
\hline textiles stores ${ }^{d}$ & 0.125 & 0.117 & 63.38 & -0.98 \\
\hline
\end{tabular}

\footnotetext{
${ }^{a}$ averages over the $1980-1995$ period

${ }^{b}$ coefficients of the fitted expenditure share equation $E S_{j t}^{f i t}=\hat{a}_{j}+\hat{b}_{j t}$ over the 1979-1995 period

${ }^{c}$ entry and exit rates are averages over the 1989-1995 period

${ }^{d}$ entry and exit rates are averages over the $1980-1988$ period
} 


\section{Acknowledgments}

Martin Carree is grateful for financial support by the Royal Netherlands Academy of Arts and Sciences (KNAW).

\section{References}

Bode, B. (1990). Studies in Retail Pricing. Ph.D. thesis, Erasmus University Rotterdam.

Bosma, N. S., \& Zwinkels, W. S. (1999). Determinanten voor toe- en uittreding van ondernemers. Research report for the Ministry of Economic Affairs (The Hague).

Carree, M., \& Thurik, R. (1996). Entry and exit in retailing: incentives, barriers, displacement and replacement. Review of Industrial Organization, 11, 155-172.

Carree, M. A., \& Thurik, A. R. (1999). The carrying capacity and entry and exit flows in retailing. International Journal of Industrial Organization, 17, 985-1007.

Dunne, T., Roberts, M. J., \& Samuelson, L. (1988). Patterns of firm entry and exit in U.S. manufacturing industries. RAND Journal of Economics, 19, 495-515.

EIM (1993). Kleinschalig ondernemen 1993. EIM Research and Consultancy (Zoetermeer).

Kirzner, I. M. (1973). Competition and entrepreneurship. Chicago: University of Chicago Press.

Kirzner, I. M. (1979). Perception, opportunity and profit: studies in the theory of entrepreneurship. Chicago: University of Chicago Press.

Kirzner, I. M. (1997). Entrepreneurial discovery and the competitive market process: an Austrian approach. Journal of Economic Literature, 35, 60-85.

Nooteboom, B. (1986). Costs, margins and competition: causes of structural change in retailing. International Journal of Research in Marketing, 3, 233-242.

Phillips, B. D. (1985). The effect of industry deregulation on the small business sector. Business Economics, 20, $28-37$.

Winston, C. (1993). Economic deregulation: days of reckoning for microeconomists. Journal of Economic Literature, 31, 1263-1289. 